\title{
Role of glycosyltransferases in carcinogenesis; growth factor signaling and EMT/MET programs
}

\author{
Motoko Takahashi $^{1}$ [ $\cdot$ Yoshihiro Hasegawa ${ }^{1} \cdot$ Kento Maeda $^{2} \cdot$ Masato Kitano $^{2} \cdot$ Naoyuki Taniguchi $^{2}$
}

Received: 2 December 2021 / Revised: 5 January 2022 / Accepted: 11 January 2022 / Published online: 28 January 2022

(c) The Author(s) 2022

\begin{abstract}
The glycosylation of cell surface receptors has been shown to regulate each step of signal transduction, including receptor trafficking to the cell surface, ligand binding, dimerization, phosphorylation, and endocytosis. In this review we focus on the role of glycosyltransferases that are involved in the modification of N-glycans, such as the effect of branching and elongation in signaling by various cell surface receptors. In addition, the role of those enzymes in the EMT/MET programs, as related to differentiation and cancer development, progress and therapy resistance is discussed.
\end{abstract}

Keywords Cell surface receptor · Collectin · EGFR $\cdot$ EMT programs $\cdot$ ErbB receptors $\cdot$ Fut8 $\cdot$ GM3 $\cdot$ GnT-III $\cdot$ GnT-V · ST6Gal1

\section{Overview of studies of $\mathrm{N}$-glycans of membrane proteins}

Most secreted proteins and membrane proteins in eukaryotic cells are glycosylated, indicating that glycosylation is important for the regulation of signal transduction [1-8]. Glycans control many of the physicochemical properties of proteins, including structure, structural stability, charge, and hydrophilicity. In the case of cell surface receptors, glycosylation has been shown to regulate each step in signal transduction such as receptor trafficking to the cell surface, ligand binding, dimerization, phosphorylation, and endocytosis $[9,10]$. To elucidate the mechanisms by which glycans control the function of these receptors, the site and the structure of the responsible glycan(s) need to be determined. To determine the site of the responsible glycan(s), a mutant receptor which lacks specific glycan(s) are used. The $\mathrm{N}$-glycan deleted

This article belongs to the Topical Collection: Tribute to Professor Sen-itiroh Hakomori

Motoko Takahashi

takam@sapmed.ac.jp

$\triangle$ Naoyuki Taniguchi tani52@wd5.so-net.ne.jp

1 Department of Biochemistry, Sapporo Medical University School of Medicine, South-1 West-17, Chuo-ku, Hokkaido 060-8556, Japan

2 Department of Glyco-Oncology and Medical Biochemistry, Osaka International Cancer Institute, 3-1-69 Otemae, Chuo-ku, Osaka 541-8567, Japan mutant receptor is established and the effects of the alteration of glycosylation site(s) on the function of the receptor can then be evaluated. For determining the structure of the responsible glycan(s), mass spectrometry analysis enables us to evaluate both the occupancy and glycan structure on each glycosylation site. By using these approaches, the function and the structure of a specific glycan can be determined. Determining glycan structure is especially important when lectin or lectin-like molecules are involved in the regulation of glycoproteins. However, it is nearly impossible to manipulate the glycan structure of a specific glycoprotein in a living cell, therefore, it is difficult to confirm the indispensability of certain glycan structures in a specific molecule. Collecting data related to the glycan function of a large number of membrane proteins might provide a clue for elucidating the roles of specific glycan structures. This review summarizes progress that has been made concerning the glycosylation of cell surface receptors.

\section{$\mathrm{N}$-glycans of ErbB receptors}

The ErbB family includes four members; EGFR (ErbB1, HER1), ErbB2 (HER2), ErbB3 (HER3), and ErbB4 (HER4). They are involved in a variety of biological events and their aberrant signaling has been implicated in the pathogenesis of various types of cancers [11, 12]. The ErbB 
receptors are classified as type I transmembrane receptor tyrosine kinases, and consist of an $\mathrm{N}$-terminal extracellular domain, a transmembrane domain, an intracellular tyrosine kinase domain, and a C-terminal tail (Fig. 1). The binding of a ligand to the extracellular domain induces a conformational change from a "tethered form (the inactive form)" to an "extended form (the active form)" in which the dimerization arm mediates homo or heterodimers [13]. The receptor dimerization induces the phosphorylation of the tyrosine residues in the $\mathrm{C}$-terminal tail, which subsequently activates the downstream signaling such as the PI3K/Akt pathway or the Ras/Erk pathway.

ErbB receptors are highly glycosylated. EGFR, ErbB2, ErbB3, and ErbB4 contain 12, 8, 10, and $11 \mathrm{~N}$-glycosylation sites, respectively, in their extracellular domains. Figure 1 indicates the N-glycosylation sites of ErbB receptors, and the alignment of glycosylation sites of ErbB receptors, and the results indicate that some glycosylation sites are common among the four ErbB receptors.

\section{N-glycans of EGFR}

EGFR is a $\sim 170 \mathrm{kDa}$ protein with 11 typical $(\mathrm{N}-\mathrm{X}-\mathrm{S} / \mathrm{T}$, where $X$ is any amino acid except proline) and 4 atypical (N-X-C) N-glycosylation consensus sequences [14]. Figure 2 indicates the occupancy and glycan structure on each $\mathrm{N}$-glycosylation site of endogenous EGFR in A431 human epidermoid carcinoma cells [15], recombinant EGFR, which is expressed in CL-1 human lung cancer cells [16], and recombinant soluble EGFR (sEGFR, the extracellular domain of EGFR) expressed in CHO-K1 cells [17]. In the case of sEGFR in CHO-K1 cells, it was observed that all 11 typical N-glycosylation consensus sequences (N104, N151, N172, N328, N337, N389, N420, N504, N544, N579, N599) are either fully or partially glycosylated, and one of the four atypical N-glycosylation consensus sequences (N32) is fully glycosylated. It should also be noted that the occupancy and glycan structures are well conserved in all cell types that have been examined to date.
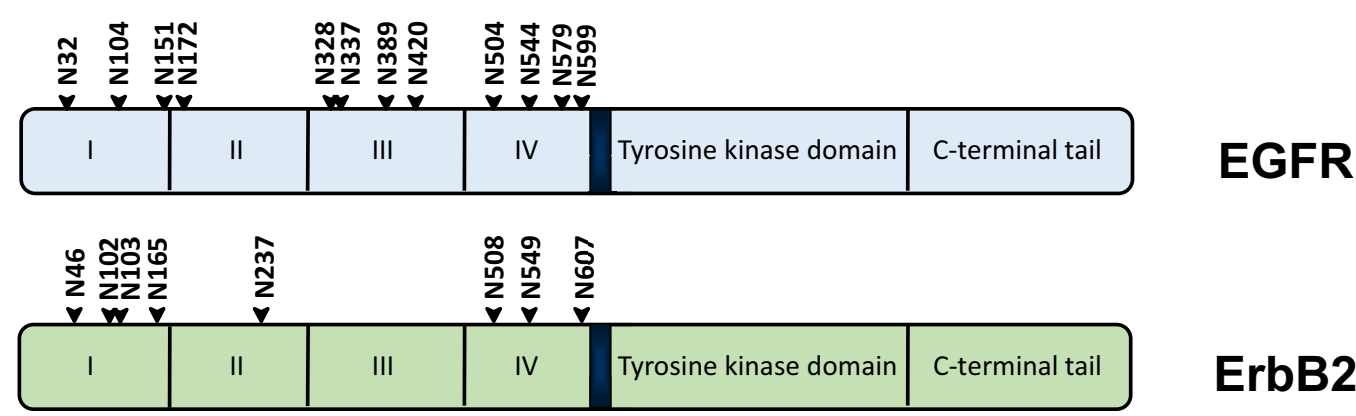

\section{ErbB2}

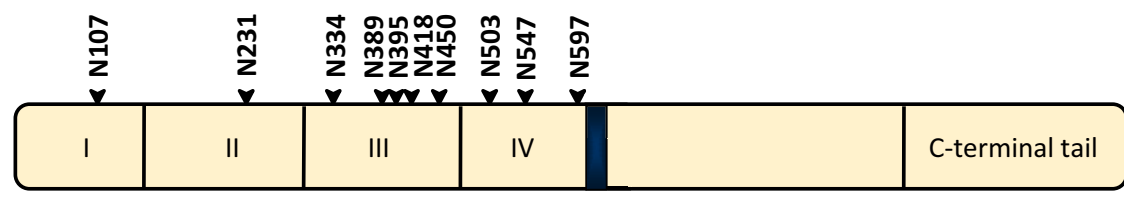

\section{ErbB3}

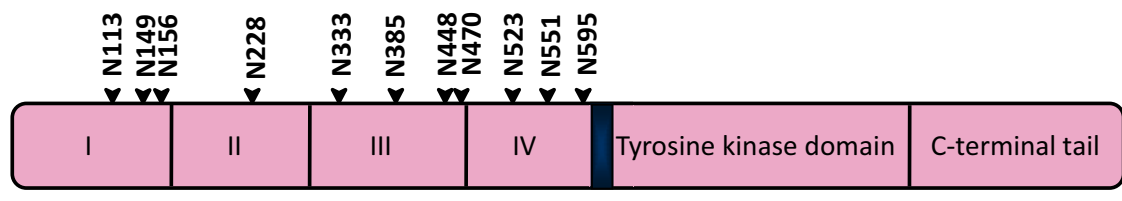

\section{ErbB4}

\begin{tabular}{|l|l|l|l|l|l|l|l|l|l|l|l|l|l|l|l|l|l|l|l|l|l|l|l|l|l|l|}
\hline domain & \multicolumn{10}{|c|}{ III } & \multicolumn{1}{|c|}{ II } & \multicolumn{10}{|c|}{ IV } \\
\hline EGFR & 32 & & & & 104 & & 151 & & 172 & & 328 & 337 & 389 & & & 420 & & & & 504 & & & 544 & & 579 & 599 \\
\hline ErbB2 & & 46 & 102 & 103 & & & & 165 & & 237 & & & & & & & & & 508 & & & 549 & & & & 607 \\
\hline ErbB3 & & & & & 107 & & & & & 231 & & 334 & & 389 & 395 & 418 & 450 & & & 503 & & & 547 & & 597 \\
\hline ErbB4 & & & & & & 113 & 149 & 156 & & 228 & & 333 & 385 & & & & 448 & 470 & & & 523 & & & 551 & 595 \\
\hline
\end{tabular}

Fig. $1 \mathrm{~N}$-glycosylation sites of ErbB receptors. The upper panel indicates the schematic diagram showing the structural protein domain and N-glycosylation sites of ErbB receptors. The amino acid numbering is for the mature form of the receptors and does not include signal peptides of the N-terminal 24 amino acids of EGFR, the 22 amino acids of ErbB2, the 19 amino acids of ErbB3, or the 25 amino acids of ErbB4. The lower panel indicates the alignment of glycosylation sites of ErbB receptors 


\begin{tabular}{|c|c|c|c|c|c|c|c|}
\hline \multicolumn{2}{|c|}{ Cell type } & \multicolumn{2}{|c|}{$\begin{array}{l}\text { Endogenous EGFR } \\
\text { in } A 431^{a}\end{array}$} & \multicolumn{2}{|c|}{$\begin{array}{l}\text { Recombinant EGFR } \\
\text { expressed In CL1-5 }\end{array}$} & \multicolumn{2}{|c|}{$\begin{array}{c}\text { Recombinant sEGFR } \\
\text { expressed in Flp-In } \mathrm{CHO}^{c}\end{array}$} \\
\hline Domain & Site & Occupancy & Glycan type & Occupancy & Glycan type & Occupancy & Glycan type \\
\hline \multirow{3}{*}{ I } & N32 & Partial & Complex & & Complex & & $\begin{array}{ll}\text { Complex } & \diamond-\square \\
& \diamond-\square\end{array}$ \\
\hline & N104 & $\times$ & N.A. & $\times$ & N.A. & Partial & 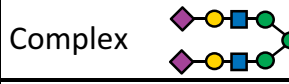 \\
\hline & N151 & & $\begin{array}{c}\text { Not } \\
\text { determined }\end{array}$ & & Complex & & $\begin{array}{ll}\text { Complex } & \diamond-\square \\
& \diamond-\square\end{array}$ \\
\hline II & N172 & $\times$ & N.A. & $x$ & N.A. & Partial & Complex ৩-০ \\
\hline \multirow{4}{*}{ III } & N328 & & $\begin{array}{c}\text { Not } \\
\text { determined } \\
\end{array}$ & & $\begin{array}{l}\text { High- } \\
\text { mannose }\end{array}$ & & High-mannose 0 \\
\hline & N337 & & $\begin{array}{c}\text { High- } \\
\text { mannose }\end{array}$ & & $\begin{array}{c}\text { High- } \\
\text { mannose }\end{array}$ & & High-mannose \\
\hline & N389 & & Complex & & Complex & & Complex \\
\hline & N420 & & Complex & & Complex & & $\begin{array}{ll}\text { Complex } & \diamond-0 \\
& \diamond-0 \\
\end{array}$ \\
\hline \multirow{4}{*}{ IV } & N504 & & Complex & & Complex & & Complex \\
\hline & N544 & $\Omega$ & Complex & & $\begin{array}{c}\text { Complex / } \\
\text { High- } \\
\text { mannose } \\
\end{array}$ & & Complex \\
\hline & N579 & Partial & $\begin{array}{c}\text { Not } \\
\text { determined }\end{array}$ & & Complex & & $\begin{array}{ll}\text { Complex } & \diamond-0 \\
& \diamond-0\end{array}$ \\
\hline & N599 & $\Omega$ & $\begin{array}{c}\text { High- } \\
\text { mannose }\end{array}$ & $\Omega$ & $\begin{array}{c}\text { High- } \\
\text { mannose }\end{array}$ & Partial & $\begin{array}{ll}\text { Complex } & \diamond-\bullet \\
& \diamond-\square\end{array}$ \\
\hline
\end{tabular}

Fig. 2 Site specific N-glycosylation status of EGFR. For each category (endogenous EGFR in A431, recombinant EGFR expressed in CL1-5, and recombinant sEGFR expressed in CHO-K1), the left column indicates glycosylation occupancy and the right column indicates the type of N-glycan. In the glycosylation occupancy columns, $\bigcirc$ indicates $100 \%$ glycosylation and $\times$ indicates no glycosylation.

The N-glycosylation of EGFR is required for ligand binding $[18,19]$, and the processing of oligosaccharides from high-mannose type to complex type does not affect this ability [20]. A site specific study has demonstrated that the N-glycan on N420 of EGFR is involved in dimerization [21]; among the four N-glycan deletion mutants of EGFR in which the glycosylation sites in domain III are mutated, the EGFR N420Q mutant exhibited ligand-independent oligomerization and phosphorylation. Another study reported that the deletion of the N-glycan on N579, which is in the domain IV auto-inhibitory tether loop, weakens the interaction between domains II and IV, thus increasing the ratio of high affinity binding receptors and also increasing the extent of ligand-independent dimerization [22]. These investigators
${ }^{\text {a } D a t a}$ from Zhen et al. [15]. The data of glycosylation status are common to full length EGFR and $105 \mathrm{kDa}$ sEGFR, but the data of the $\mathrm{N}$-glycan structure are of $105 \mathrm{kDa}$ sEGFR. ${ }^{\mathrm{b}}$ Data from Liu et al. [16]. $100 \%$ glycosylation and partial glycosylation are not discriminated here. ${ }^{c}$ Data from Hasegawa et al. [17]

assumed that N-glycan attached to N579 contributes to the stability of the inactive form, and that the deletion of the $\mathrm{N}$-glycan might increase the structural flexibility of the moleculs. These studies suggest that specific N-glycans might be involved in stabilizing structure of EGFR to prevent unnecessary activation. Molecular dynamics simulation studies have also demonstrated that $\mathrm{N}$-glycans are determinants of EGFR conformation, including the orientation of the extracellular domain relative to the membrane [23].

Glycan structures are also important for regulating EGFR when lectins or lectin-like molecules are involved. For example, in a previous study, we reported that the pulmonary surfactant protein D (SP-D) downregulates EGF signaling in lung adenocarcinoma $[17,24]$. SP-D is an apoprotein of 
a pulmonary surfactant, belongs to the collectin subgroup of the C-type lectin superfamily which recognizes highmannose type $\mathrm{N}$-glycans in a calcium dependent manner $[25,26]$. We have reported that SP-D directly binds to the $\mathrm{N}$-glycans of EGFR, and downregulates the binding of EGF to EGFR and downstream signaling in human lung adenocarcinoma cells [17, 24]. As shown in Fig. 2, EGFR contains high-mannose type N-glycans at N328 and N337, and SP-D possibly binds to these glycans. It is speculated that the binding of SP-D to EGFR directly interferes with EGF binding, or that SP-D affects the conformation of EGFR, thus altering the ligand binding characteristics of the molecule.

It has been reported that EGFR with poly- $N$-acetyllactosamine (poly-LacNAc) containing $\mathrm{N}$-glycans, which is produced by the enzymatic activity of $\mathrm{N}$-acetylglucosaminyltransferase V (GnT-V), avoids constitutive endocytosis [27]. It has been proposed that galectin-3 binds to poly-LacNAc on the glycans of EGFR to form a molecular lattice, leading to the cell surface expression of EGFR being sustained. Intriguingly, it has been observed that the endocytosis of EGFR is increased in $\mathrm{N}$-acetylglucosaminyltransferase III (GnT-III) transfected HeLaS3 cells [28]. GnT-III catalyzes the introduction of a GlcNAc unit to produce a "bisecting GlcNAc" structure [29], which prevents the formation of poly-LacNAc. It is possible that the binding of N-glycans of EGFR to galectin-3 is decreased by the activity of GnT-III, resulting in the upregulation of EGFR endocytosis. A case can be made that specific structures of $\mathrm{N}$-glycans may regulate EGFR endocytosis through interactions with galectin-3.

The $\alpha 1,6$-fucosylation of $\mathrm{N}$-glycans by the activity of $\alpha 1,6$ fucosyltransferase (Fut8) has been shown to affect EGFR function [30]. Fut8 catalyzes the addition of a fucose unit to the innermost GlcNAc residue of N-glycans, to produce $\alpha 1,6$-fucosylation, or a "core fucose" [31]. We previously reported that the loss of $\alpha 1,6$-fucosylation of $\mathrm{N}$-glycans of EGFR reduces the binding of EGF to EGFR, and subsequent downstream signaling [30]. It has also been suggested that the increased sialylation and $\alpha 1,3$ fucosylation of the N-glycans of EGFR suppress EGF-induced EGFR dimerization [16, 32].

Hakomori et al. demonstrated that glycosphingolipids modulate transmembrane signaling and indicated that glycosphingolipid enriched microdomains are signaling platforms [1, 2, 33, 34]. EGFR is also regulated by glycoshpingolipids. GM3 (NeuAc $\alpha 3$ Gal $\beta 4$ Glc $\beta 1 \mathrm{Cer}$ ) has been shown to interact with EGFR and downregulate its activation [35-41]. The binding activity of GM3 is much higher than that for other gangliosides, such as GM2, GD3, GM4, GM1, GD1a, and GT1b [40]. It has been reported that GM3 interacts with complex-type N-glycans with multivalent GlcNAc termini through carbohydrate-to-carbohydrate interactions (CCI). GM3 binds to the $\mathrm{N}$-glycans of EGFR and inhibits the activation of tyrosine kinase and subsequent downstream signaling without affecting ligand binding activity [42, 43]. GM3 also inhibits EGFR tyrosine kinase activity by interacting with a membrane proximal lysine residue, K642 [44]. It has also been demonstrated that membrane-associated sialidase NEU3, whose selective substrates are GM3 and GD1a [45], activates EGFR [46]. It has been reported that GM3 is involved in the development of cancer [47-49].

\section{N-glycans of ErbB3}

ErbB3 is a receptor for neuregulin1 (heregulin), neuregulin 2, and neuregulin 6. The unique character of ErbB3 is its lack of tyrosine kinase activity [50]. Therefore, ErbB3 forms a heterodimer with other ErbB receptors and exerts downstream signaling, such as the PI3K/Akt pathway or Ras/Erk pathway. The activation of PI3K/Akt signaling has been implicated in the ErbB3-dependent progression of various types of cancer [51-53]. The induction of ErbB3 expression or signaling is an important factor in drug resistance in several cancer models. Because of the above findings, ErbB3 is considered to be a promising target for cancer therapy $[54,55]$.

ErbB3 is a $\sim 185 \mathrm{kDa}$ protein with $10 \mathrm{~N}$-glycosylation consensus sequences in the extracellular domain. Figure 3 provides a summary of the occupancy and glycan structure on each $\mathrm{N}$-glycosylation site of recombinant soluble ErbB3

\begin{tabular}{|c|c|c|c|c|}
\hline \multicolumn{2}{|c|}{ Cell type } & \multicolumn{2}{|c|}{$\begin{array}{c}\text { Recombinant sErbB3 } \\
\text { expressed in Flp-In } \mathrm{CHO}^{\mathrm{a}}\end{array}$} & \\
\hline Domain & Site & Occupancy & Glycan type & \\
\hline I & N107 & & Complex & 숨 \\
\hline II & N231 & & $\begin{array}{l}\text { Complex / } \\
\text { High-mannose }\end{array}$ & \\
\hline \multirow{5}{*}{ III } & N334 & & Complex & \\
\hline & N389 & & High-mannose & \\
\hline & N395 & & High-mannose & \\
\hline & N418 & & Complex & \\
\hline & N450 & 2 & Complex & \\
\hline \multirow{3}{*}{ IV } & N503 & ○ & Complex & \\
\hline & N547 & Partial & Complex & \\
\hline & N597 & Partial & Complex & \\
\hline
\end{tabular}

Fig. 3 Site specific N-glycosylation status of ErbB3. In the glycosylation occupancy columns, $\bigcirc$ indicates $100 \%$ glycosylation and $\times$ indicates no glycosylation. ${ }^{a}$ Data from Takahashi et al. (under submission) 
that is expressed in CHO-K1 cells. The N-glycan on N418 of ErbB3, which corresponds to N420 of EGFR based on sequence alignment (Fig. 1), is involved in dimer formation. Among the 10 single N-glycan deletion mutants of ErbB3, the ErbB3 N418Q mutant forms a heterodimer with ErbB2 without ligand stimulation, exerts downstream signaling and promotes tumor formation in athymic mice [56]. These findings suggest that the $\mathrm{N}$-glycans play a role in maintaining the inactive form of ErbB receptors in the absence of a ligand. It is possible that the conformational changes from the inactive form to the active form in the $\mathrm{N}$-glycan deletion mutant of ErbB3 N418Q requires less energy [57].

The extracellular domain of ErbB3 (= soluble ErbB3, sErbB3) exerts suppressive effects on heregulin signaling, and these effects are enhanced in N418Q mutant $[58,59]$. It is possible that the frequency of binding of the sErbB3 N418Q mutant to ErbB2 or other receptors on the cell surface is higher than that of the wild type [10].

\section{EMT/MET Programs and glycans of cell surface receptor}

We previously reviewed the role of $\mathrm{N}$-glycosylation of several cell surface receptors such as TGF- $\beta$ receptor, RTKs, Integrins, Wnt, Hedgehog, Notch, and the involvement of glycans in inflammation and hypoxia-induced EMT (endothelial-mesenchymal transition) in various kinds of diseases $[9,60]$. It is well known that phenotypic changes due to EMT play pivotal roles during embryonic development [61-64], wound healing [65], cancer and fibrosis [66]. Especially in cancer, invasion, metastasis and chemoresistance are considered to be highly associated with EMT [67]. The significance of EMT was also reported in COPD (chronic obstructive pulmonary disease) [68, 69], interstitial pneumonitis [70], and lung cancer [69]. Moreover, EMT has also been implicated in resistance to therapy in cancer $[67,71]$. It has also been reported that EMT contributes to the development of resistance to the EGFR-tyrosine kinase inhibitor in non-small cell lung cancer [72]. The implication of COVID-19 infection has been also reported [73].

It was recently reported that an intermediate type of cell, referred to as a hybrid cell is produced between EMT and its reversive process, MET (mesenchymal-epithelial transition) [74-76]. A classical type of EMT programs were reported to be rather one-way processes, but recently it has become recognized that the EMT programs are more dynamic and can sometimes be reversed by epigenetic modification and gene regulation. There are distinct biomarkers for EMT and MET [77]. Among them, E-cadherin, claudin, occludin, and cytokeratin are typical examples because the gene expression patterns of these molecules are activated in MET and downregulated in EMT. On the other hand, N-cadherin, collagen, matrix metalloproteinases, fibronectin and vimentin are highly upregulated in EMT and downregulated in MET. There are also EMT transcription factors such as the Snail family referred to as SNAIL(SNAI1), SLUG (SNAI2) and SMUG (SNAI3), the basic helix-loop-helix protein family referred to as TWIST1 and TWIST2, and zing finger E-box binding transcription factors, referred to as ZEB1 and ZEB2 [67]. However, the issue of biomarkers for hybrid cells remains unclear at this time.

During EMT programs, the most important hallmark is TGF- $\beta$ activation in various cancers. At the early stage of cancer, TGF- $\beta$ acts as a protective factor whereas during carcinogenesis TGF- $\beta$ functions as a progressive factor [78]. TGF- $\beta$ is essential in developmental period as well. For example, TGF- $\beta$ signaling facilitates the embryonic development of the lung and the aberrant glycosylation of TGF- $\beta$ decreases signaling and downregulates the phosphorylation of Smad, thus causing emphysematous changes [79, 80].

EGFR stimulates EMT during differentiation processes and apoptosis of cancer cells [81-83]. Resistance to therapy due to EGFR signaling has been reported [81]. Involvement of glycosphingolipids in EMT has also been demonstrated [84]. From these facts, changes in glycans in cell surface receptors may also play important roles in EMT and MET processes. Our group reported on the significance of branched $\mathrm{N}$-glycans in various diseases, and in the case of EMT, our findings indicate that some glycosyltransferase genes of N-glycan branching and extension such as GnT-V, Fut8 and ST6Gal1 are upregulated in case of MET, whereas GnT-III is downregulated [85, 86] as shown in Fig. 4. However, the expressions of those genes may be sometimes upregulated in both EMT and MET, and probably at the intermediate stage, i.e. in the hybrid cells, some of these enzyme expressions are reversible [60, 87, 88]. Response to reduction-oxidation (redox) is one of the most important biological phenomena for maintaining homeostasis of the body under conditions of various types of oxidative stress [89] under pathophysiological conditions. Our group has been interested in redox regulation under conditions of oxidative stress as well as glycobiology in relation to disease [90-94]. Functional and structural changes in glycans are regulated by redox responses resulting from the generation of reactive oxygen species (ROS) or reactive nitrogen species (RNS) in various diseases including cancer [95], diabetes [96], neurodegenerative diseases [97], such as Parkinson's disease, Alzheimer's disease as well as amyotrophic lateral sclerosis (ALS) (87), COPD [98] and aging. We proposed that the field "glyco-redox" investigations will open avenues to developing a more comprehensive understanding of the mechanism associated with diseases, as related to changes in glycan structures under oxidative stress [90]. The significance of this interplay was also reported by other groupes $[99,100]$. It is well known that signaling molecules such as 
Fig. 4 EMT/MET programs and changes in glycosyltransferases. Various effects of GnT-V, Fut8, ST6Gal1 and GnT-III in EMT/ MET programs. GnT-III is implicated in the MET whereas ST6Gal1, GnT-V and Fut8 are implicated in EMT and it is possible that these changes are stimulated by various factors such as signaling molecules related to oxidative stress, via various signaling molecules including transcription factors such as ZEB1, 2, which are implicated in both EMT and MET

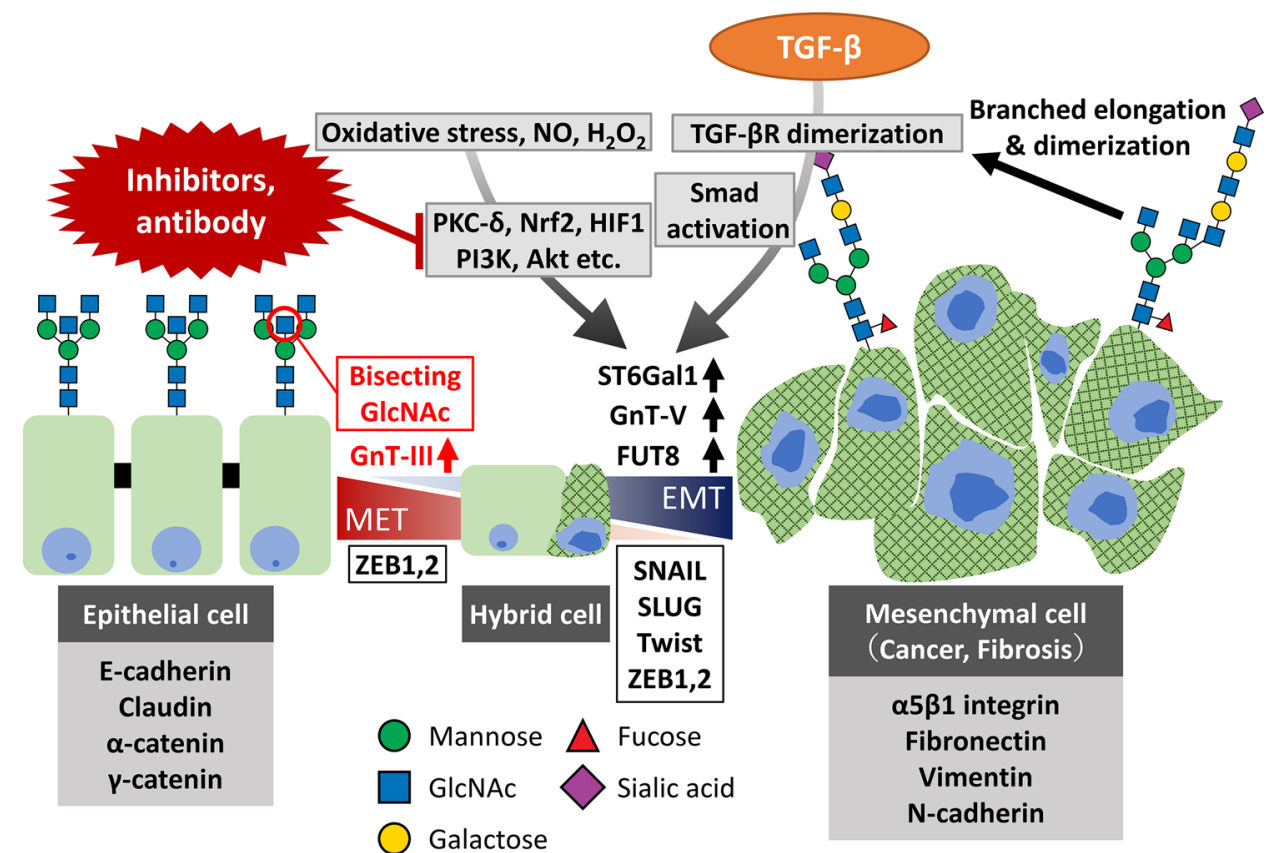

PI3K/Akt [101], PKC-delta [102], Nrf2 [103], HIF1 [104] and Smad [105] are closely associated with redox regulation. Some of these signaling molecules also regulate the activities of glycosyltransferases that are involved in $\mathrm{N}$-glycan biosynthesis such as ST6Gal1 [106], GnT-V and Fut8, etc.. It has also been reported that some transcription factors that regulate GnT-III, V, and Fut8 as well as ST6Gal1 may play key roles in the intermediate states. In order to regulate the EMT programs for preventing cancer development, progression, metastasis and therapy resistance, specific antibodies or specific inhibitors against various transcription factors toward N-glycan glycosyltransferases are likely candidates for novel therapeutics in the future as shown in Fig. 4.

Acknowledgements This work has been supported by JSPS KAKENHI Grant Numbers 21K06083 for MT and 18K06914 for NT, and by Japan Agency for Medical Research and Development (AMED) (20ac011070h005). We apologize for not citing all relevant papers due to space limitations. We wish to acknowledge Dr. Milton Feather for his English editing.

Data availability statement The data that support the findings of this study are available from the corresponding author upon reasonable request.

\section{Compliance with ethical standards}

Conflict of interest The authors declare that they have no conflicts of interest with the contents of this article.

Ethical approval This article does not contain any studies with human participants or animals performed by any of the authors.
Open Access This article is licensed under a Creative Commons Attribution 4.0 International License, which permits use, sharing, adaptation, distribution and reproduction in any medium or format, as long as you give appropriate credit to the original author(s) and the source, provide a link to the Creative Commons licence, and indicate if changes were made. The images or other third party material in this article are included in the article's Creative Commons licence, unless indicated otherwise in a credit line to the material. If material is not included in the article's Creative Commons licence and your intended use is not permitted by statutory regulation or exceeds the permitted use, you will need to obtain permission directly from the copyright holder. To view a copy of this licence, visit http://creativecommons.org/licenses/by/4.0/.

\section{References}

1. Hakomori, S.: Glycosphingolipids in cellular interaction, differentiation, and oncogenesis. Annu. Rev. Biochem. 50, 733-764 (1981). https://doi.org/10.1146/annurev.bi.50.070181.003505

2. Hakomori, S., Handa, K., Iwabuchi, K., Yamamura, S., Prinetti, A.: New insights in glycosphingolipid function: "glycosignaling domain," a cell surface assembly of glycosphingolipids with signal transducer molecules, involved in cell adhesion coupled with signaling. Glycobiology 8(10), xi-xix (1998). https://doi. org/10.1093/oxfordjournals.glycob.a018822

3. Imperiali, B., O'Connor, S.E.: Effect of N-linked glycosylation on glycopeptide and glycoprotein structure. Curr. Opin. Chem. Biol. 3(6), 643-649 (1999)

4. Haltiwanger, R.S., Lowe, J.B.: Role of glycosylation in development. Annu. Rev. Biochem. 73, 491-537 (2004). https://doi.org/ 10.1146/annurev.biochem.73.011303.074043

5. Ohtsubo, K., Marth, J.D.: Glycosylation in cellular mechanisms of health and disease. Cell 126(5), 855-867 (2006). https://doi. org/10.1016/j.cell.2006.08.019 
6. Taniguchi, N., Miyoshi, E., Gu, J., Honke, K., Matsumoto, A.: Decoding sugar functions by identifying target glycoproteins. Curr. Opin. Struct. Biol. 16(5), 561-566 (2006). https://doi.org/ 10.1016/j.sbi.2006.08.011

7. Lau, K.S., Dennis, J.W.: N-Glycans in cancer progression. Glycobiology 18(10), 750-760 (2008). https://doi.org/10.1093/glycob/ cwn071

8. Varki, A.: Biological roles of glycans. Glycobiology 27(1), 3-49 (2017). https://doi.org/10.1093/glycob/cww086

9. Takahashi, M., Kizuka, Y., Ohtsubo, K., Gu, J., Taniguchi, N.: Disease-associated glycans on cell surface proteins. Mol. Aspects Med. 51, 56-70 (2016). https://doi.org/10.1016/j.mam.2016.04. 008

10. Takahashi, M., Hasegawa, Y., Gao, C., Kuroki, Y., Taniguchi, $\mathrm{N}$.: N-glycans of growth factor receptors: their role in receptor function and disease implications. Clin. Sci. (Lond). 130(20), 1781-1792 (2016). https://doi.org/10.1042/CS20160273

11. Arteaga, C.L., Engelman, J.A.: ERBB receptors: from oncogene discovery to basic science to mechanism-based cancer therapeutics. Cancer Cell 25(3), 282-303 (2014). https://doi. org/10.1016/j.ccr.2014.02.025

12. Kovacs, E., Zorn, J.A., Huang, Y., Barros, T., Kuriyan, J.: A structural perspective on the regulation of the epidermal growth factor receptor. Annu. Rev. Biochem. 84, 739-764 (2015). https://doi.org/10.1146/annurev-biochem-060614-034402

13. Dawson, J.P., Bu, Z., Lemmon, M.A.: Ligand-induced structural transitions in ErbB receptor extracellular domains. Structure 15(8), 942-954 (2007). https://doi.org/10.1016/j.str.2007. 06.013

14. Sato, C., Kim, J.H., Abe, Y., Saito, K., Yokoyama, S., Kohda, D.: Characterization of the $\mathrm{N}$-oligosaccharides attached to the atypical Asn-X-Cys sequence of recombinant human epidermal growth factor receptor. J. Biochem. 127(1), 65-72 (2000)

15. Zhen, Y., Caprioli, R.M., Staros, J.V.: Characterization of glycosylation sites of the epidermal growth factor receptor. Biochemistry 42(18), 5478-5492 (2003). https://doi.org/10.1021/ bi027101p

16. Liu, Y.C., Yen, H.Y., Chen, C.Y., Chen, C.H., Cheng, P.F., Juan, Y.H., Chen, C.H., Khoo, K.H., Yu, C.J., Yang, P.C., Hsu, T.L., Wong, C.H.: Sialylation and fucosylation of epidermal growth factor receptor suppress its dimerization and activation in lung cancer cells. Proc. Natl. Acad. Sci. U.S.A. 108(28), 11332-11337 (2011). https://doi.org/10.1073/pnas.1107385108

17. Hasegawa, Y., Takahashi, M., Ariki, S., Asakawa, D., Tajiri, M., Wada, Y., Yamaguchi, Y., Nishitani, C., Takamiya, R., Saito, A., Uehara, Y., Hashimoto, J., Kurimura, Y., Takahashi, H., Kuroki, Y.: Surfactant protein D suppresses lung cancer progression by downregulation of epidermal growth factor signaling. Oncogene 34(7), 838-845 (2015). https://doi.org/10.1038/onc.2014.20

18. Soderquist, A.M., Carpenter, G.: Glycosylation of the epidermal growth factor receptor in A-431 cells. The contribution of carbohydrate to receptor function. J. Biol. Chem. 259(20), 1258612594 (1984).

19. Gamou, S., Shimizu, N.: Glycosylation of the epidermal growth factor receptor and its relationship to membrane transport and ligand binding. J. Biochem. 104(3), 388-396 (1988)

20. Slieker, L.J., Lane, M.D.: Post-translational processing of the epidermal growth factor receptor. Glycosylation-dependent acquisition of ligand-binding capacity. J. Biol. Chem. 260(2), 687-690 (1985).

21. Tsuda, T., Ikeda, Y., Taniguchi, N.: The Asn-420-linked sugar chain in human epidermal growth factor receptor suppresses ligand-independent spontaneous oligomerization. Possible role of a specific sugar chain in controllable receptor activation. J. Biol. Chem. 275(29), 21988-21994 (2000). https://doi.org/10. 1074/jbc.M003400200
22. Whitson, K.B., Whitson, S.R., Red-Brewer, M.L., McCoy, A.J., Vitali, A.A., Walker, F., Johns, T.G., Beth, A.H., Staros, J.V.: Functional effects of glycosylation at Asn-579 of the epidermal growth factor receptor. Biochemistry 44(45), 14920-14931 (2005). https://doi.org/10.1021/bi050751j

23. Kaszuba, K., Grzybek, M., Orlowski, A., Danne, R., Rog, T., Simons, K., Coskun, U., Vattulainen, I.: N-Glycosylation as determinant of epidermal growth factor receptor conformation in membranes. Proc. Natl. Acad. Sci. U.S.A. 112(14), 4334-4339 (2015). https://doi.org/10.1073/pnas.1503262112

24. Umeda, Y., Hasegawa, Y., Otsuka, M., Ariki, S., Takamiya, R., Saito, A., Uehara, Y., Saijo, H., Kuronuma, K., Chiba, H., Ohnishi, H., Sakuma, Y., Takahashi, H., Kuroki, Y., Takahashi, M.: Surfactant protein $\mathrm{D}$ inhibits activation of non-small cell lung cancerassociated mutant EGFR and affects clinical outcomes of patients. Oncogene 36(46), 6432-6445 (2017). https://doi.org/10.1038/onc. 2017.253

25. Kuroki, Y., Voelker, D.R.: Pulmonary surfactant proteins. J. Biol. Chem. 269(42), 25943-25946 (1994)

26. Whitsett, J.A., Weaver, T.E.: Hydrophobic surfactant proteins in lung function and disease. N. Engl. J. Med. 347(26), 2141-2148 (2002). https://doi.org/10.1056/NEJMra022387

27. Partridge, E.A., Le Roy, C., Di Guglielmo, G.M., Pawling, J., Cheung, P., Granovsky, M., Nabi, I.R., Wrana, J.L., Dennis, J.W.: Regulation of cytokine receptors by Golgi N-glycan processing and endocytosis. Science 306(5693), 120-124 (2004). https:// doi.org/10.1126/science.1102109

28. Sato, Y., Takahashi, M., Shibukawa, Y., Jain, S.K., Hamaoka, R., Miyagawa, J., Yaginuma, Y., Honke, K., Ishikawa, M., Taniguchi, $\mathrm{N} .:$ Overexpression of $\mathrm{N}$-acetylglucosaminyltransferase III enhances the epidermal growth factor-induced phosphorylation of ERK in HeLaS3 cells by up-regulation of the internalization rate of the receptors. J. Biol. Chem. 276(15), 11956-11962 (2001). https:// doi.org/10.1074/jbc.M008551200

29. Nishikawa, A., Ihara, Y., Hatakeyama, M., Kangawa, K., Taniguchi, N.: Purification, cDNA cloning, and expression of UDP-N-acetylglucosamine: beta-D-mannoside beta-1,4Nacetylglucosaminyltransferase III from rat kidney. J. Biol. Chem. 267(25), 18199-18204 (1992)

30. Wang, X., Gu, J., Ihara, H., Miyoshi, E., Honke, K., Taniguchi, N.: Core fucosylation regulates epidermal growth factor receptormediated intracellular signaling. J. Biol. Chem. 281(5), 25722577 (2006). https://doi.org/10.1074/jbc.M510893200

31. Uozumi, N., Yanagidani, S., Miyoshi, E., Ihara, Y., Sakuma, T., Gao, C.X., Teshima, T., Fujii, S., Shiba, T., Taniguchi, N.: Purification and cDNA cloning of porcine brain GDP-L-Fuc:Nacetyl-beta-D-glucosaminide alpha1->6fucosyltransferase. J. Biol. Chem. 271(44), 27810-27817 (1996)

32. Yen, H.Y., Liu, Y.C., Chen, N.Y., Tsai, C.F., Wang, Y.T., Chen, Y.J., Hsu, T.L., Yang, P.C., Wong, C.H.: Effect of sialylation on EGFR phosphorylation and resistance to tyrosine kinase inhibition. Proc. Natl. Acad. Sci. U.S.A. 112(22), 6955-6960 (2015). https://doi.org/10.1073/pnas.1507329112

33. Iwabuchi, K., Handa, K., Hakomori, S.: Separation of "glycosphingolipid signaling domain" from caveolin-containing membrane fraction in mouse melanoma B16 cells and its role in cell adhesion coupled with signaling. J. Biol. Chem. 273(50), 33766-33773 (1998). https://doi.org/10.1074/jbc.273.50.33766

34. Iwabuchi, K., Zhang, Y., Handa, K., Withers, D.A., Sinaÿ, P., Hakomori, S.: Reconstitution of membranes simulating "glycosignaling domain" and their susceptibility to lyso-GM3. J. Biol. Chem. 275(20), 15174-15181 (2000). https://doi.org/10. 1074/jbc.275.20.15174

35. Bremer, E.G., Schlessinger, J., Hakomori, S.: Ganglioside-mediated modulation of cell growth. Specific effects of GM3 on tyrosine 
phosphorylation of the epidermal growth factor receptor. J. Biol. Chem. 261(5), 2434-2440 (1986).

36. Hakomori, S.: Bifunctional role of glycosphingolipids. Modulators for transmembrane signaling and mediators for cellular interactions. J. Biol. Chem. 265(31), 18713-18716 (1990).

37. Weis, F.M., Davis, R.J.: Regulation of epidermal growth factor receptor signal transduction. Role of gangliosides. J. Biol. Chem. 265(20), 12059-12066 (1990).

38. Zhou, Q., Hakomori, S., Kitamura, K., Igarashi, Y.: GM3 directly inhibits tyrosine phosphorylation and de-N-acetyl-GM3 directly enhances serine phosphorylation of epidermal growth factor receptor, independently of receptor-receptor interaction. J. Biol. Chem. 269(3), 1959-1965 (1994)

39. Allende, M.L., Proia, R.L.: Lubricating cell signaling pathways with gangliosides. Curr. Opin. Struct. Biol. 12(5), 587-592 (2002)

40. Miljan, E.A., Meuillet, E.J., Mania-Farnell, B., George, D., Yamamoto, H., Simon, H.G., Bremer, E.G.: Interaction of the extracellular domain of the epidermal growth factor receptor with gangliosides. J. Biol. Chem. 277(12), 10108-10113 (2002). https://doi.org/10.1074/jbc.M111669200

41. Hakomori, S.I., Handa, K.: GM3 and cancer. Glycoconj. J. 32(12), 1-8 (2015). https://doi.org/10.1007/s10719-014-9572-4

42. Kawashima, N., Yoon, S.J., Itoh, K., Nakayama, K.: Tyrosine kinase activity of epidermal growth factor receptor is regulated by GM3 binding through carbohydrate to carbohydrate interactions. J. Biol. Chem. 284(10), 6147-6155 (2009). https://doi.org/ 10.1074/jbc.M808171200

43. Yoon, S.J., Nakayama, K., Hikita, T., Handa, K., Hakomori, S.I.: Epidermal growth factor receptor tyrosine kinase is modulated by GM3 interaction with N-linked GlcNAc termini of the receptor. Proc. Natl. Acad. Sci. U.S.A. 103(50), 18987-18991 (2006). https://doi.org/10.1073/pnas.0609281103

44. Coskun, U., Grzybek, M., Drechsel, D., Simons, K.: Regulation of human EGF receptor by lipids. Proc. Natl. Acad. Sci. U.S.A. 108(22), 9044-9048 (2011). https://doi.org/10.1073/ pnas. 1105666108

45. Hasegawa, T., Yamaguchi, K., Wada, T., Takeda, A., Itoyama, Y., Miyagi, T.: Molecular cloning of mouse ganglioside sialidase and its increased expression in Neuro2a cell differentiation. J. Biol. Chem. 275(11), 8007-8015 (2000)

46. Wada, T., Hata, K., Yamaguchi, K., Shiozaki, K., Koseki, K., Moriya, S., Miyagi, T.: A crucial role of plasma membrane-associated sialidase in the survival of human cancer cells. Oncogene 26(17), 2483-2490 (2007). https://doi.org/10.1038/sj.onc.1210341

47. Miyata, M., Kambe, M., Tajima, O., Moriya, S., Sawaki, H., Hotta, H., Kondo, Y., Narimatsu, H., Miyagi, T., Furukawa, K., Furukawa, K.: Membrane sialidase NEU3 is highly expressed in human melanoma cells promoting cell growth with minimal changes in the composition of gangliosides. Cancer Sci. 102(12), 2139-2149 (2011). https://doi.org/10.1111/j.1349-7006.2011. 02086.x

48. Shiozaki, K., Yamaguchi, K., Sato, I., Miyagi, T.: Plasma membrane-associated sialidase (NEU3) promotes formation of colonic aberrant crypt foci in azoxymethane-treated transgenic mice. Cancer Sci. 100(4), 588-594 (2009). https://doi.org/10. 1111/j.1349-7006.2008.01080.x

49. Tringali, C., Lupo, B., Silvestri, I., Papini, N., Anastasia, L., Tettamanti, G., Venerando, B.: The plasma membrane sialidase NEU3 regulates the malignancy of renal carcinoma cells by controlling beta1 integrin internalization and recycling. J. Biol. Chem. 287(51), 42835-42845 (2012). https://doi.org/10.1074/ jbc.M112.407718

50. Jura, N., Shan, Y., Cao, X., Shaw, D.E., Kuriyan, J.: Structural analysis of the catalytically inactive kinase domain of the human
EGF receptor 3. Proc. Natl. Acad. Sci. U.S.A. 106(51), 21608 21613 (2009). https://doi.org/10.1073/pnas.0912101106

51. Cook, R.S., Garrett, J.T., Sanchez, V., Stanford, J.C., Young, C., Chakrabarty, A., Rinehart, C., Zhang, Y., Wu, Y., Greenberger, L., Horak, I.D., Arteaga, C.L.: ErbB3 ablation impairs PI3K/Aktdependent mammary tumorigenesis. Can. Res. 71(11), 39413951 (2011). https://doi.org/10.1158/0008-5472.CAN-10-3775

52. Smirnova, T., Zhou, Z.N., Flinn, R.J., Wyckoff, J., Boimel, P.J., Pozzuto, M., Coniglio, S.J., Backer, J.M., Bresnick, A.R., Condeelis, J.S., Hynes, N.E., Segall, J.E.: Phosphoinositide 3-kinase signaling is critical for ErbB3-driven breast cancer cell motility and metastasis. Oncogene 31(6), 706-715 (2012). https://doi.org/10.1038/onc.2011.275

53. Young, C.D., Pfefferle, A.D., Owens, P., Kuba, M.G., Rexer, B.N., Balko, J.M., Sanchez, V., Cheng, H., Perou, C.M., Zhao, J.J., Cook, R.S., Arteaga, C.L.: Conditional loss of ErbB3 delays mammary gland hyperplasia induced by mutant PIK3CA without affecting mammary tumor latency, gene expression, or signaling. Can. Res. 73(13), 4075-4085 (2013). https://doi.org/10.1158/0008-5472.CAN-12-4579

54. Baselga, J., Swain, S.M.: Novel anticancer targets: revisiting ERBB2 and discovering ERBB3. Nat. Rev. Cancer 9(7), 463-475 (2009). https://doi.org/10.1038/nrc2656

55. Campbell, M.R., Amin, D., Moasser, M.M.: HER3 comes of age: new insights into its functions and role in signaling, tumor biology, and cancer therapy. Clinical cancer research : an official journal of the American Association for Cancer Research 16(5), 1373-1383 (2010). https://doi.org/10.1158/1078-0432. CCR-09-1218

56. Yokoe, S., Takahashi, M., Asahi, M., Lee, S.H., Li, W., Osumi, D., Miyoshi, E., Taniguchi, N.: The Asn418-linked N-glycan of ErbB3 plays a crucial role in preventing spontaneous heterodimerization and tumor promotion. Can. Res. 67(5), 1935-1942 (2007). https://doi.org/10.1158/0008-5472.CAN-06-3023

57. Takahashi, M., Yokoe, S., Asahi, M., Lee, S.H., Li, W., Osumi, D., Miyoshi, E., Taniguchi, N.: N-glycan of ErbB family plays a crucial role in dimer formation and tumor promotion. Biochem. Biophys. Acta. 1780(3), 520-524 (2008). https://doi.org/ 10.1016/j.bbagen.2007.10.019

58. Takahashi, M., Hasegawa, Y., Ikeda, Y., Wada, Y., Tajiri, M., Ariki, S., Takamiya, R., Nishitani, C., Araki, M., Yamaguchi, Y., Taniguchi, N., Kuroki, Y.: Suppression of heregulin beta signaling by the single $\mathrm{N}$-glycan deletion mutant of soluble ErbB3 protein. J. Biol. Chem. 288(46), 32910-32921 (2013). https://doi.org/10.1074/jbc.M113.491902

59. Takamiya, R., Takahashi, M., Uehara, Y., Ariki, S., Hashimoto, J., Hasegawa, Y., Kuroki, Y.: The single N-glycan deletion mutant of soluble ErbB3 protein attenuates heregulin beta1induced tumor progression by blocking of the HIF-1 and Nrf2 pathway. Biochem. Biophys. Res. Commun. 454(3), 364-368 (2014). https://doi.org/10.1016/j.bbrc.2014.10.086

60. Taniguchi, N.: Glycans in disease: From diagnosis to therapeutics and beyond. Mol. Aspects Med. 79,(2021)

61. Hay, E.D., Zuk, A.: Transformations between epithelium and mesenchyme: normal, pathological, and experimentally induced. Am. J. Kidney Dis. 26(4), 678-690 (1995). https:// doi.org/10.1016/0272-6386(95)90610-x

62. Thiery, J.P., Acloque, H., Huang, R.Y., Nieto, M.A.: Epithelialmesenchymal transitions in development and disease. Cell 139(5), 871-890 (2009). https://doi.org/10.1016/j.cell.2009.11.007

63. Nieto, M.A., Huang, R.Y., Jackson, R.A., Thiery, J.P.: Emt: 2016. Cell 166(1), 21-45 (2016). https://doi.org/10.1016/j.cell. 2016.06.028

64. Yang, M.H., Wu, M.Z., Chiou, S.H., Chen, P.M., Chang, S.Y., Liu, C.J., Teng, S.C., Wu, K.J.: Direct regulation of TWIST 
by HIF-1alpha promotes metastasis. Nat. Cell Biol. 10(3), 295-305 (2008). https://doi.org/10.1038/ncb1691

65. Arnoux, V., Nassour, M., L'Helgoualc'h, A., Hipskind, R.A., Savagner, P.: Erk5 controls Slug expression and keratinocyte activation during wound healing. Mol. Biol. Cell 19(11), 4738-4749 (2008). https://doi.org/10.1091/mbc.E07-10-1078

66. Wynn, T.A.: Cellular and molecular mechanisms of fibrosis. J. Pathol. 214(2), 199-210 (2008). https://doi.org/10.1002/path. 2277

67. Yang, J., Cui, R., Liu, Y.: MicroRNA-212-3p inhibits paclitaxel resistance through regulating epithelial-mesenchymal transition, migration and invasion by targeting ZEB2 in human hepatocellular carcinoma. Oncol. Lett. 20(4), 23 (2020). https://doi. org/10.3892/ol.2020.11884

68. Eapen, M.S., Sharma, P., Thompson, I.E., Lu, W., Myers, S., Hansbro, P.M., Sohal, S.S.: Heparin-binding epidermal growth factor (HB-EGF) drives EMT in patients with COPD: implications for disease pathogenesis and novel therapies. Lab. Invest. 99(2), 150-157 (2019). https://doi.org/10.1038/ s41374-018-0146-0

69. Sohal, S.S.: Epithelial and endothelial cell plasticity in chronic obstructive pulmonary disease (COPD). Respir. Investig. 55(2), 104-113 (2017). https://doi.org/10.1016/j.resinv.2016.11.006

70. Gaikwad, A.V., Eapen, M.S., McAlinden, K.D., Chia, C., Larby, J., Myers, S., Dey, S., Haug, G., Markos, J., Glanville, A.R., Sohal, S.S.: Endothelial to mesenchymal transition (EndMT) and vascular remodeling in pulmonary hypertension and idiopathic pulmonary fibrosis. Expert Rev. Respir. Med. 14(10), 1027-1043 (2020). https://doi.org/10.1080/17476348. 2020.1795832

71. Zhang, J., Miller, Z., Musich, P.R., Thomas, A.E., Yao, Z.Q., Xie, Q., Howe, P.H., Jiang, Y.: DSTYK Promotes Metastasis and Chemoresistance via EMT in Colorectal Cancer. Front. Pharmacol. 11, 1250 (2020). https://doi.org/10.3389/fphar.2020.01250

72. Tulchinsky, E., Demidov, O., Kriajevska, M., Barlev, N.A., Imyanitov, E.: EMT: A mechanism for escape from EGFR-targeted therapy in lung cancer. Biochim. Biophys. Acta. Rev. Cancer. 1871(1), 29-39 (2019). https://doi.org/10.1016/j.bbcan.2018.10. 003

73. Stewart, C.A., Gay, C.M., Ramkumar, K., Cargill, K.R., Cardnell, R.J., Nilsson, M.B., Heeke, S., Park, E.M., Kundu, S.T., Diao, L., Wang, Q., Shen, L., Xi, Y., Zhang, B., Della Corte, C.M., Fan, Y., Kundu, K., Gao, B., Avila, K., Pickering, C.R., Johnson, F.M., Zhang, J., Kadara, H., Minna, J.D., Gibbons, D.L., Wang, J., Heymach, J.V., Byers, L.A.: Lung Cancer Models Reveal Severe Acute Respiratory Syndrome Coronavirus 2-Induced Epithelialto-Mesenchymal Transition Contributes to Coronavirus Disease 2019 Pathophysiology. J. Thorac. Oncol. 16(11), 1821-1839 (2021). https://doi.org/10.1016/j.jtho.2021.07.002

74. Pastushenko, I., Blanpain, C.: EMT Transition States during Tumor Progression and Metastasis. Trends Cell Biol. 29(3), 212-226 (2019). https://doi.org/10.1016/j.tcb.2018.12.001

75. Pastushenko, I., Brisebarre, A., Sifrim, A., Fioramonti, M., Revenco, T., Boumahdi, S., Van Keymeulen, A., Brown, D., Moers, V., Lemaire, S., De Clercq, S., Minguijon, E., Balsat, C., Sokolow, Y., Dubois, C., De Cock, F., Scozzaro, S., Sopena, F., Lanas, A., D'Haene, N., Salmon, I., Marine, J.C., Voet, T., Sotiropoulou, P.A., Blanpain, C.: Identification of the tumour transition states occurring during EMT. Nature 556(7702), 463-468 (2018). https://doi.org/ 10.1038/s41586-018-0040-3

76. Yang, J., Antin, P., Berx, G., Blanpain, C., Brabletz, T., Bronner, M., Campbell, K., Cano, A., Casanova, J., Christofori, G., Dedhar, S., Derynck, R., Ford, H.L., Fuxe, J., Garcia de Herreros, A., Goodall, G.J., Hadjantonakis, A.K., Huang, R.Y.J., Kalcheim, C., Kalluri, R., Kang, Y., Khew-Goodall, Y., Levine, H., Liu, J., Longmore, G.D., Mani, S.A., Massague, J., Mayor, R., McClay, D., Mostov, K.E.,
Newgreen, D.F., Nieto, M.A., Puisieux, A., Runyan, R., Savagner, P., Stanger, B., Stemmler, M.P., Takahashi, Y., Takeichi, M., Theveneau, E., Thiery, J.P., Thompson, E.W., Weinberg, R.A., Williams, E.D., Xing, J., Zhou, B.P., Sheng, G., Association, E.M.T.I.: Guidelines and definitions for research on epithelial-mesenchymal transition. Nature reviews. Mol. Cell. Biol. 21(6), 341-352 (2020). https://doi. org/10.1038/s41580-020-0237-9

77. Alidadiani, N., Ghaderi, S., Dilaver, N., Bakhshamin, S., Bayat, M.: Epithelial mesenchymal transition Transcription Factor (TF): The structure, function and microRNA feedback loop. Gene 674, 115-120 (2018). https://doi.org/10.1016/j.gene.2018.06.049

78. Katsuno, Y., Lamouille, S., Derynck, R.: TGF-beta signaling and epithelial-mesenchymal transition in cancer progression. Curr. Opin. Oncol. 25(1), 76-84 (2013). https://doi.org/10.1097/CCO. 0b013e32835b6371

79. Wang, X., Inoue, S., Gu, J., Miyoshi, E., Noda, K., Li, W., Mizuno-Horikawa, Y., Nakano, M., Asahi, M., Takahashi, M., Uozumi, N., Ihara, S., Lee, S.H., Ikeda, Y., Yamaguchi, Y., Aze, Y., Tomiyama, Y., Fujii, J., Suzuki, K., Kondo, A., Shapiro, S.D., Lopez-Otin, C., Kuwaki, T., Okabe, M., Honke, K., Taniguchi, N.: Dysregulation of TGF-beta1 receptor activation leads to abnormal lung development and emphysema-like phenotype in core fucose-deficient mice. Proc. Natl. Acad. Sci. U.S.A. 102(44), 15791-15796 (2005). https://doi.org/10.1073/pnas.0507375102

80. Wang, X., Gu, J., Miyoshi, E., Honke, K., Taniguchi, N.: Phenotype changes of Fut 8 knockout mouse: core fucosylation is crucial for the function of growth factor receptor(s). Methods Enzymol. 417, 11-22 (2006). https://doi.org/10.1016/S00766879(06)17002-0

81. Byers, L.A., Diao, L., Wang, J., Saintigny, P., Girard, L., Peyton, M., Shen, L., Fan, Y., Giri, U., Tumula, P.K., Nilsson, M.B., Gudikote, J., Tran, H., Cardnell, R.J., Bearss, D.J., Warner, S.L., Foulks, J.M., Kanner, S.B., Gandhi, V., Krett, N., Rosen, S.T., Kim, E.S., Herbst, R.S., Blumenschein, G.R., Lee, J.J., Lippman, S.M., Ang, K.K., Mills, G.B., Hong, W.K., Weinstein, J.N., Wistuba, I.I., Coombes, K.R., Minna, J.D., Heymach, J.V.: An epithelial-mesenchymal transition gene signature predicts resistance to EGFR and PI3K inhibitors and identifies Axl as a therapeutic target for overcoming EGFR inhibitor resistance. Clinical cancer research : an official journal of the American Association for Cancer Research 19(1), 279-290 (2013). https://doi.org/10.1158/1078-0432.CCR-12-1558

82. Al Moustafa, A.E., Achkhar, A., Yasmeen, A.: EGF-receptor signaling and epithelial-mesenchymal transition in human carcinomas. Front. Biosci. (Schol Ed) 4, 671-684 (2012). https:// doi.org/10.2741/s292

83. Brabletz, S., Schuhwerk, H., Brabletz, T., Stemmler, M.P.: Dynamic EMT: a multi-tool for tumor progression. The EMBO J. 40(18), e108647 (2021). https://doi.org/10.15252/embj. 2021108647

84. Guan, F., Handa, K., Hakomori, S.I.: Specific glycosphingolipids mediate epithelial-to-mesenchymal transition of human and mouse epithelial cell lines. Proc. Natl. Acad. Sci. U.S.A. 106(18), 7461-7466 (2009). https://doi.org/10.1073/pnas.0902368106

85. Pinho, S.S., Oliveira, P., Cabral, J., Carvalho, S., Huntsman, D., Gartner, F., Seruca, R., Reis, C.A., Oliveira, C.: Loss and recovery of Mgat3 and GnT-III Mediated E-cadherin N-glycosylation is a mechanism involved in epithelial-mesenchymal-epithelial transitions. PLoS ONE 7(3), e33191 (2012). https://doi.org/10. 1371/journal.pone.0033191

86. Xu, Q., Isaji, T., Lu, Y., Gu, W., Kondo, M., Fukuda, T., Du, Y., $\mathrm{Gu}$, J.: Roles of N-acetylglucosaminyltransferase III in epithelialto-mesenchymal transition induced by transforming growth factor beta1 (TGF-beta1) in epithelial cell lines. J. Biol. Chem. 287(20), 16563-16574 (2012). https://doi.org/10.1074/jbc.M111. 262154 
87. Terao, M., Ishikawa, A., Nakahara, S., Kimura, A., Kato, A., Moriwaki, K., Kamada, Y., Murota, H., Taniguchi, N., Katayama, I., Miyoshi, E.: Enhanced epithelial-mesenchymal transitionlike phenotype in $\mathrm{N}$-acetylglucosaminyltransferase $\mathrm{V}$ transgenic mouse skin promotes wound healing. J. Biol. Chem. 286(32), 28303-28311 (2011). https://doi.org/10.1074/jbc.M111.220376

88. Taniguchi, N., Ohkawa, Y., Maeda, K., Harada, Y., Nagae, M., Kizuka, Y., Ihara, H., Ikeda, Y.: True significance of $\mathrm{N}$-acetylglucosaminyltransferases GnT-III, V and alpha1,6 fucosyltransferase in epithelial-mesenchymal transition and cancer. Mol. Aspects Med. 79,(2021)

89. Sies, H.: Oxidative stress: a concept in redox biology and medicine. Redox Biol. 4, 180-183 (2015). https://doi.org/10.1016/j. redox.2015.01.002

90. Taniguchi, N., Kizuka, Y., Takamatsu, S., Miyoshi, E., Gao, C., Suzuki, K., Kitazume, S., Ohtsubo, K.: Glyco-redox, a link between oxidative stress and changes of glycans: Lessons from research on glutathione, reactive oxygen and nitrogen species to glycobiology. Arch. Biochem. Biophys. 595, 72-80 (2016). https://doi.org/10.1016/j.abb.2015.11.024

91. Kizuka, Y., Nakano, M., Kitazume, S., Saito, T., Saido, T.C., Taniguchi, N.: Bisecting GlcNAc modification stabilizes BACE1 protein under oxidative stress conditions. Biochem. J. 473(1), 21-30 (2016). https://doi.org/10.1042/BJ20150607

92. Ota, F., Kizuka, Y., Kitazume, S., Adachi, T., Taniguchi, N.: $\mathrm{N}$-Glycosylation is essential for the secretion of extracellular superoxide dismutase. FEBS. Lett. 590(19), 3357-3367 (2016). https://doi.org/10.1002/1873-3468.12378

93. Kurimoto, A., Kitazume, S., Kizuka, Y., Nakajima, K., Oka, R., Fujinawa, R., Korekane, H., Yamaguchi, Y., Wada, Y., Taniguchi, N.: The absence of core fucose up-regulates GnT-III and Wnt target genes: a possible mechanism for an adaptive response in terms of glycan function. J. Biol. Chem. 289(17), 11704-11714 (2014). https://doi.org/10.1074/jbc.M113.502542

94. Takamiya, R., Takahashi, M., Myint, T., Park, Y.S., Miyazawa, N., Endo, T., Fujiwara, N., Sakiyama, H., Misonou, Y., Miyamoto, Y., Fujii, J., Taniguchi, N.: Glycation proceeds faster in mutated $\mathrm{Cu}$, $\mathrm{Zn}$-superoxide dismutases related to familial amyotrophic lateral sclerosis. FASEB. J. 17(8), 938-940 (2003). https://doi.org/10. 1096/fj.02-0768fje

95. Klaunig, J.E.: Oxidative Stress and Cancer. Curr. Pharm. Des. 24(40), 4771-4778 (2018). https://doi.org/10.2174/1381612825 666190215121712

96. Newsholme, P., Cruzat, V.F., Keane, K.N., Carlessi, R., de Bittencourt, P.I., Jr.: Molecular mechanisms of ROS production and oxidative stress in diabetes. Biochem. J. 473(24), 4527-4550 (2016). https://doi.org/10.1042/BCJ20160503C
97. Yan, M.H., Wang, X., Zhu, X.: Mitochondrial defects and oxidative stress in Alzheimer disease and Parkinson disease. Free Radic. Biol. Med. 62, 90-101 (2013). https://doi.org/10.1016/j. freeradbiomed.2012.11.014

98. Nagai, K., Betsuyaku, T., Kondo, T., Nasuhara, Y., Nishimura, M.: Long term smoking with age builds up excessive oxidative stress in bronchoalveolar lavage fluid. Thorax 61(6), 496-502 (2006). https://doi.org/10.1136/thx.2005.049148

99. Blois, S.M., Prince, P.D., Borowski, S., Galleano, M., Barrientos, G.: Placental Glycoredox Dysregulation Associated with Disease Progression in an Animal Model of Superimposed Preeclampsia. Cells 10(4) (2021). https://doi.org/10.3390/cells10040800

100. Khoder-Agha, F., Kietzmann, T.: The glyco-redox interplay: Principles and consequences on the role of reactive oxygen species during protein glycosylation. Redox Biol. 42,(2021)

101. Hoxhaj, G., Manning, B.D.: The PI3K-AKT network at the interface of oncogenic signalling and cancer metabolism. Nat. Rev. Cancer 20(2), 74-88 (2020). https://doi.org/10.1038/ s41568-019-0216-7

102. Xu, X., Sun, S., Xie, F., Ma, J., Tang, J., He, S., Bai, L.: Advanced oxidation protein products induce epithelialmesenchymal transition of intestinal epithelial cells via a PKC delta-mediated redox-dependent signaling pathway. Antioxid. Redox Signal. 27(1), 37-56 (2017). https://doi.org/10.1089/ ars.2015.6611

103. Yamamoto, M., Kensler, T.W., Motohashi, H.: The KEAP1NRF2 System: a Thiol-Based Sensor-Effector Apparatus for Maintaining Redox Homeostasis. Physiol. Rev. 98(3), 1169-1203 (2018). https://doi.org/10.1152/physrev.00023.2017

104. Semenza, G.L.: Hypoxia-inducible factors: coupling glucose metabolism and redox regulation with induction of the breast cancer stem cell phenotype. The EMBO J. 36(3), 252-259 (2017). https://doi.org/10.15252/embj.201695204

105. Samarakoon, R., Overstreet, J.M., Higgins, P.J.: TGF-beta signaling in tissue fibrosis: redox controls, target genes and therapeutic opportunities. Cell. Signal. 25(1), 264-268 (2013). https://doi. org/10.1016/j.cellsig.2012.10.003

106. Jones, R.B., Dorsett, K.A., Hjelmeland, A.B., Bellis, S.L.: The ST6Gal-I sialyltransferase protects tumor cells against hypoxia by enhancing HIF-1alpha signaling. J. Biol. Chem. 293(15), 5659-5667 (2018). https://doi.org/10.1074/jbc.RA117.001194

Publisher's Note Springer Nature remains neutral with regard to jurisdictional claims in published maps and institutional affiliations. 